Article

\title{
Evaluation of Seasonal and Synoptic Changes in Snow Accumulation in Antarctica between Five Reanalyses Products and In Situ Observations
}

\author{
Yihui Liu, Fei Li * and Weifeng Hao \\ Chinese Antarctic Center of Surveying and Mapping, Wuhan University, Wuhan 430079, China; \\ liuyihuichn@whu.edu.cn (Y.L.); haoweifengchn@foxmail.com (W.H.) \\ * Correspondence: flichn@whu.edu.cn
}

Received: 8 September 2018; Accepted: 30 November 2018; Published: 3 December 2018

check for updates

\begin{abstract}
The performance of recent reanalysis products (i.e., ERA-Interim, NCEP2, MERRA, CFSR, and JRA-55) was evaluated based on in situ observations from nine automatic weather stations and one stake network to investigate the monthly and seasonal variability of the surface mass balance in Antarctica. Synoptic precipitation simulations were also evaluated by an investigation of high precipitation events. The seasonal variations showed large fluctuations and were inconsistent at each station, probably owing to the large interannual variability of snow accumulation based on the short temporal coverage of the data. The ERA-Interim and JRA-55 datasets revealed better simulated precision, with the other three models presenting similar simulations at monthly and seasonal timescales. The JRA-55 dataset captured a greater number of synoptic high precipitation events at four of the nine stations. Such events at the other five stations were mainly captured by ERA and CFSR. The NCEP2 dataset was more weakly correlated with each station on all timescales. These results indicate that significant monthly or seasonal correlations between in situ observations and the models had little effect on the capability of the reanalyses to capture high precipitation events. The precision of the five reanalysis datasets widely fluctuated in specific regions or at specific stations at different timescales. Great caution is needed when using a single reanalysis dataset to assess the surface mass balance over all of Antarctica.
\end{abstract}

Keywords: high precipitation events; atmospheric reanalyses; precipitation evaluation

\section{Introduction}

Ice sheets are important contributors to global sea levels in the context of global warming [1]. The Antarctic ice sheet is the largest in the world, and global sea levels could increase by $>56 \mathrm{~m}$ if it completely melted [2]. However, it is difficult to accurately determine the mass balance of the Antarctic ice sheet with the sparse and nonconsecutive in situ observations currently available, leading to controversy about its evolution. Although an increasing loss of ice has been indicated by the Gravity Recovery and Climate Experiment and InSAR radar altimetry satellite measurements [3,4], Zwally et al. (2015) showed mass gain increases as a result of global warming [5].

To address this discrepancy, the surface mass balance (SMB) needs to be quantified accurately. SMB is defined as the total gain or loss of ice/snow mass at the surface of an ice sheet. Accumulation is the total mass gain caused by snowfall or snowdrift which could also cause ablation. Ablation is the total mass loss at the surface caused by melting, evaporation, or wind erosion [6,7]. Owing to the low temperature of Antarctica, the impact of surface melting on surface snow accumulation can be ignored [7]. Even if high precipitation events were rare during the process of mass gain, they dominated the SMB [6-8]. Therefore, an understanding of these events is required to correctly interpret the ice cores, and the variability in snow accumulation at a synoptic timescale must also be quantified [9-12]. 
Precipitation climatology is influenced by steep topography, which forces air to rise $[7,13]$. A cliff-like ice slope influences the amount of precipitation generated by changing the direction of moist air moving poleward to one parallel to the contours at its edge [14]. The air becomes drier and colder during uplift, leading to separation of the wet coastal and dry interior regions and increasing precipitation in escarpment regions lower than $3000 \mathrm{~m}$ [14-16]. Snow accumulation on the Antarctic plateau (higher than $3000 \mathrm{~m}$ ) depends on clear sky precipitation or diamond dust caused by the radiative cooling of air rather than on snowfall $[7,14]$. Although the mechanisms differ, high precipitation events are influenced by synoptic weather systems, such as vertical motion forcing, sufficient moisture, and static instability $[13,14]$.

The inherent challenges related to measuring precipitation in Antarctica have not been resolved $[17,18]$. In coastal areas, it is difficult to separate precipitation from snow blown by strong katabatic winds. In the interior of the ice sheet, where rates of precipitation are very low $[19,20]$, sensors must be able to detect very light precipitation. Many attempts have been made to examine Antarctic snow accumulation using remote sensing and ground-based measurements, which give a better evaluation of large-scale snow accumulation in Antarctica [20-22]. However, applying satellite data to specific regions and all of Antarctica at a synoptic timescale is limited due to relatively low spatial and temporal resolution. SMB components still need to be quantified by ground-based measurements. The spatial or time resolution of other ground-based determination methods-such as stake measurements at a single site, snow pits, ice cores, and ground-penetrating radar-cannot meet the requirements for accuracy at a synoptic timescale.

As a result of the sparseness of in situ and satellite measurements, atmospheric reanalysis datasets have been widely used as a key tool to measure snow accumulation [23-26]. Although the simulations have been constantly improved, hydrological variables from numerical simulation models should be used with caution [27-29]. It is necessary to verify the reanalyses using in situ observations before using them to estimate the spatial and temporal variability of SMB in Antarctica [28]. The results of the reanalyses for precipitation minus surface evaporation have been widely used as the simulated SMB in Antarctica [23,30,31], and the precision of model simulations has been primarily assessed by in situ observations in multiple studies [26,30-33]. A comparison between annual SMB in Antarctica from six reanalyses (ERA-I, ERA-40, NCEP-2, MERRA, CFSR, and JRA-25) has been made based on in situ observations covering 1989-2009 [26,34]. This comparison suggested that ERA-I likely offers the most realistic depiction of annual SMB changes in Antarctica during 1989-2009. During that time, the positive trends in Antarctic SMB in NCEP2, JRA-25, and MERRA were exaggerated. This result was also corroborated by previous studies [23,35]. In Adelie Land, ERA-I did quite a better job than ERA-40, which overestimated the coastal SMB due to its topographical mismatch [30]. In the coastal regions of the Shirase Glacier drainage basin, JRA-55, MERRA, and ERA-I reported annual simulations similar with the observed SMB. In East Antarctica, ERA-I also provided more accurate interannual variability of SMB than MERRA and JRA-55 between 1979 and 2012 [36].

These evaluations assessed the performance of SMB simulations in reanalysis datasets at annual or longer timescales for the entire ice sheet $[26,30-32,36]$. Only a few attempts have been made to assess the performance of simulated precipitation for reanalyses and regional atmospheric model datasets at a synoptic timescale. These attempts were based on field observations in Antarctica, such as those in Dronning Maud land (DML) [13,16,18,37,38], the Ross Ice Shelf [39], and Dome Fuji [40]. However, no study has attempted to assess the uncertainty of the five reanalysis datasets using in situ observations at synoptic timescales for the entire ice sheet, Wilkes Land, or Marie Byrd Land. These reanalysis datasets are the European Centre for Medium-Range Weather Forecasts (ECMWF) ERA-Interim reanalysis dataset (ERA-I) [41], the National Centers for Environmental Prediction (NCEP), the Department of Energy Atmospheric Model Intercomparison Project 2 reanalysis dataset (NCEP2) [42], the Modern-Era Retrospective Analysis for Research and Applications (MERRA) dataset [43], the NCEP Climate Forecast System Reanalyses (CFSR) [44], and the Japan Meteorological Agency 55-year Reanalysis (JRA-55) dataset [45]. 
Additionally, Schlosser et al. (2016) measured precipitation directly $1 \mathrm{~m}$ above the snow surface to reduce the impact of low drifting snow [46]. Daily snow samples were measured using plastic containers located on the Dome Fuji station roof [40]. However, such field observations were not automatically given and time series observations were insufficient. The measurements were also discontinuous and contained unquantifiable errors. The vertical profiles of radar effective reflectivity, Doppler velocity, and spectral width were derived from the micro-rain radar-2 (MRR) with $24 \mathrm{GHz}$ offered by the German company Metek Meteorologische Messtechnik (Metek) [47,48]. The advantage of this radar is that it can directly measure precipitation and capture large samples at high resolution $[17,49,50]$. The precipitation rate in $\mathrm{mm} /$ hour is derived from radar reflectivity (Z)-snowfall rate (S) relationships based on the microphysical properties of snowfall [17,48]. However, the radar is located in the coastal area with a perfect logistic service system, and precipitation cannot be measured at lower atmospheric levels $(<300 \mathrm{~m})$ due to poor vertical resolution $(100 \mathrm{~m})[48,50]$. Measurements with more advanced precipitation radars are very valuable for comparison but they have been limited only to a summer term or short campaigns [51].

The ultrasonic sensors installed on automatic weather stations (AWSs) measure the distance from the sensor to the snow surface. The ultrasonic sensors (i.e., the Campbell SR50 acoustic depth gauges) measure the changes in snow height automatically with a high temporal resolution of $10 \mathrm{~min}$ and accuracy of $0.01 \mathrm{~m}[52,53]$. Snow accumulation is a complex process that includes snowfall, wind-driven sublimation, erosion, and compaction [54]. The impact of the wind in both methods cannot be removed entirely $[17,46]$. Other ablation processes show little effect on the evaluation of high snow accumulation events at synoptic timescales in Antarctica [13,38,39]. Previous studies have suggested that high accumulation events identified by a certain threshold are induced by precipitation at a synoptic timescale, and in situ measurements could be used to assess the performance of precipitation in reanalyses $[8,13,39]$. Thus, ultrasonic sensors are currently the best ground-based method to determine extreme or high snow accumulation events and to evaluate the performance of reanalyses in all of Antarctica for successive years at a synoptic timescale [7,39].

The reanalyses need to be verified using field observations before they can be used to investigate the spatial and temporal variability in Antarctic SMB. However, few attempts have been made to evaluate the ability of the five reanalyses in simulating regional snow accumulation at a synoptic timescale. In situ observations from AWSs with a very high temporal resolution are useful in evaluating the simulation accuracy of reanalysis datasets at different timescales. Our primary objective in this study was to evaluate to what extent the recent reanalyses capture the synoptic changes in snow accumulation and to evaluate the reanalysis products for SMB variability at monthly and seasonal timescales. We accomplished this by comparing them to quality-controlled in situ observations in Antarctica. The spatial and temporal variability in SMB was also investigated for different regions of Antarctica. This comprehensive comparison between in situ observations and reanalyses will help improve the model by identifying biases of the current models.

\section{Experiments}

\subsection{In Situ Observations}

We collected hourly and daily surface accumulations of snow measured by stake networks at the South Pole and by acoustic depth gauges (ADGs) installed at nine AWSs located from the coast to the inland plateau of Antarctica (Figure 1). Table 1 provides their location, length of records, and elevation. Snow accumulation measurements were available for various time periods at AWSs from February 2008 to June 2015 and at the South Pole from January 1983 to June 2015. The South Pole and Evans Knoll stations had the longest (32.5 years) and shortest (2 years) records, respectively. The measurements were continuous at each station, except for Siple Dome, Dome A, and D-47, which were missing data for 6, 7, and 19 months, respectively. The in situ observations at three stations (Dome A, Eagle, and Panda) were provided by the Chinese National Antarctic Research Expedition program, and the 
observations at seven other stations were provided by the Antarctic Meteorological Research Center (AMRC) and Automatic Weather Station program, which are United States Antarctic Program sister projects. The continuous snow accumulation measurements are valuable and sparse due to the harsh environment in Antarctica. Snow accumulation measurements at only one or two stations with limited time coverage have been used to evaluate the regional weather situation $[8,13]$. The in situ observations with limited time coverage also have been used to evaluate the performance of reanalyses in Antarctica [13,39]. Thus, the in situ observations in this study are of particular importance.

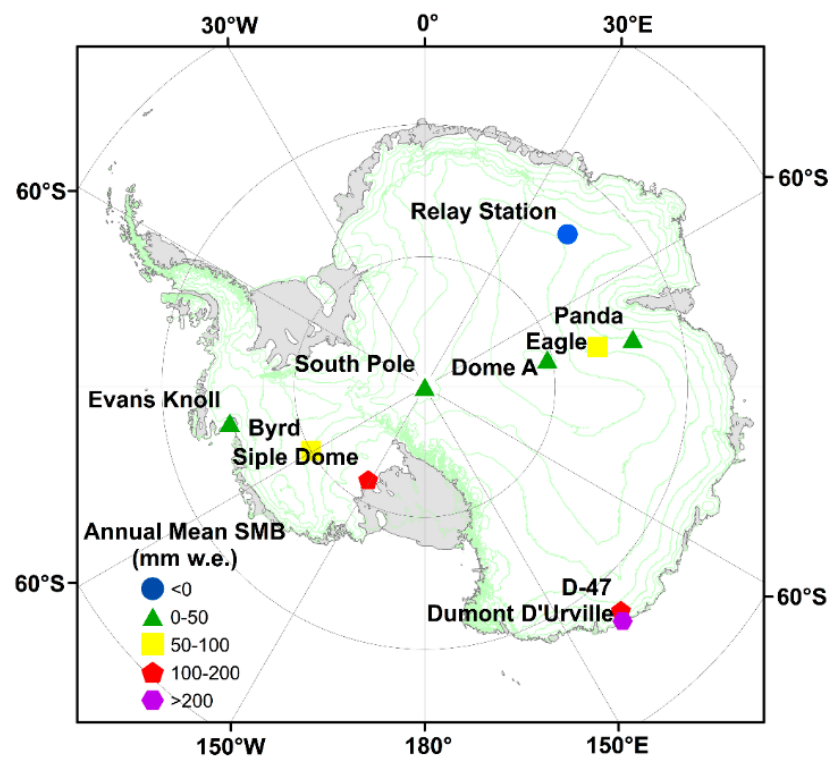

Figure 1. Map of Antarctica showing the locations of the 10 automatic weather stations (AWSs). The different colors show the different ranges of annual surface mass balance (SMB). Time coverage varied between stations, as shown in Table 1 .

Table 1. Locations, lengths of records, and elevations of the AWSs.

\begin{tabular}{|c|c|c|c|c|c|}
\hline \multirow{2}{*}{ Station Name } & \multicolumn{2}{|c|}{ Location } & \multirow{2}{*}{ AWS Data } & \multirow{2}{*}{ Data Length (yr) } & \multirow{2}{*}{ Elev. $(\mathrm{m})$} \\
\hline & Latitude & Longitude & & & \\
\hline Byrd & $80.007^{\circ} \mathrm{S}$ & $119.404^{\circ} \mathrm{W}$ & November 2011-June 2015 & 3.7 & 1530 \\
\hline D-47 & $67.397^{\circ} \mathrm{S}$ & $138.726^{\circ} \mathrm{E}$ & February 2011-June 2015 & 2.8 & 1550 \\
\hline Relay Station & $74.017^{\circ} \mathrm{S}$ & $43.062^{\circ} \mathrm{E}$ & February 2010-June 2015 & 5.4 & 3353 \\
\hline Evans Knoll & $74.85^{\circ} \mathrm{S}$ & $100.404^{\circ} \mathrm{W}$ & January 2011-December 2012 & 2 & 188 \\
\hline Dumont D'Urville & $66.71^{\circ} \mathrm{S}$ & $139.83^{\circ} \mathrm{E}$ & February 2008-November 2011 & 3.8 & 243 \\
\hline Siple Dome & $81.656^{\circ} \mathrm{S}$ & $148.773^{\circ} \mathrm{W}$ & January 2012-June 2015 & 3 & 667.6 \\
\hline South Pole & $90^{\circ} \mathrm{S}$ & 0 & January 1983-June 2015 & 32.5 & 3800 \\
\hline Dome A & $80.367^{\circ} \mathrm{S}$ & $77.374^{\circ} \mathrm{E}$ & January 2005-December 2014 & 9.4 & 4084 \\
\hline Eagle & $76.42^{\circ} \mathrm{S}$ & $77.024^{\circ} \mathrm{E}$ & January 2006-December 2014 & 9 & 2830 \\
\hline Panda & $73.689^{\circ} \mathrm{S}$ & $76.967^{\circ} \mathrm{E}$ & January 2012-December 2014 & 3 & 2584 \\
\hline
\end{tabular}

Changes in snow height at nine AWSs were measured every 10 min with a Campbell SR50 ADG, with an accuracy of $0.01 \mathrm{~m}$ or $0.04 \%$ of the sensor height. Because the snow accumulation was determined by reflected sonic pulses from sensors, the measurements contained noise caused by drifting snow, frost on the sensors, high wind speeds $(>18 \mathrm{~m} / \mathrm{s}$ ), and extremely low temperatures (less than $\left.-35^{\circ} \mathrm{C}\right)[52,53]$. Although the ADG data at six stations was corrected based on the temperature provided by the University of Wisconsin AMRC ftp site (ftp:/ / amrc.ssec.wisc.edu) [55], there were some null measurements (e.g., 444) and meaningless measurements that were abnormally large or small (e.g., $17.8 \mathrm{~m}$, which is larger than the distance between the sensors and snow surface). These obvious noises were removed first. Then, the nonphysical accumulation measurements were also removed [51,56]. Such measurements had the same order of magnitude as the correct measurements, but they showed impossible and sudden changes in snow height in just $10 \mathrm{~min}$ (the observation 
interval of the ADG), and they were separate and outside the initial and final accumulation values. Additionally, snow accumulation is a continuous and stepped process [53]. Thus, the remaining high-frequency noise was minimized based on a threshold algorithm [17,53]. This methodology uses one standard deviation of the daily average value of 10-min snow accumulation measurements to remove high-frequency noise while allowing the amplitude of snow accumulation to be retained. Snow accumulation measurements at the South Pole were compiled by stake networks (a grid of $6 \times 6$ stakes placed at $20 \mathrm{~m}$ intervals) [57]. The in situ observations on the South Pole were provided by the University of Wisconsin AMRC ftp site (ftp:/ / amrc.ssec.wisc.edu). The stakes were 2.5-m long and 15-25 mm in diameter and were installed on a horizontal slab fixed $60-90 \mathrm{~cm}$ deep in the snowpack. The stakes were measured twice monthly (at an average interval of 15.3 days) at a resolution of $5 \mathrm{~mm}$ [57]. To analyze the SMB at each station, the snow depth was multiplied by snow density. The snow density was assumed to be $350 \mathrm{~kg} / \mathrm{m}^{3}$ at all stations due to its large fluctuations [39]. The measurements were accumulated to a daily and monthly resolution with the reanalysis simulations for comparison.

\subsection{Reanalyses Data}

The simulated results of the reanalysis (precipitation minus surface evaporation/sublimation) data have been previously confirmed to approximate the Antarctic SMB [23,31,32]. We used in situ observations to assess the accuracy of synoptic and seasonal simulations using five global atmospheric reanalysis products: ERA-I, NCEP2, MERRA, CFSR, and JRA-55. The time periods of the reanalyses used for this study were the same as the in situ observations for each of the stations shown in Table 1 . The reanalyses were available free on their respective websites: http:/ /apps.ecmwf.int/datasets / for ERA-I, https:/ / www.esrl.noaa.gov / for NCEP2, https:/ / disc.gsfc.nasa.gov / daac-bin/ for MERRA, https:/ /nomads.ncdc.noaa.gov / data / for CFSR, and http:/ /jra.kishou.go.jp for JRA-55. Additionally, the assimilation data of the five reanalyses did not use snow accumulation measurements from the 10 stations in this study.

ERA-I replaced the 40-year ECMWF reanalysis dataset (ERA-40) to generate a global atmospheric model simulation spanning the entire 20th century (1979-2018). It had 60 vertical levels and a T255 spectral model with a modified assimilation system. The new four-dimensional variational analysis system has an improved humidity analysis and a corrected satellite radiance bias [41,58,59].

NCEP2 was developed from the Reanalyses I model with updated boundary conditions covering 1979-2018 [42,60]. The sea surface temperature data were derived from the ECMWF reanalyses and interpolated to daily values [61]. The NCEP2 precipitation rate and latent heat net flux products have a temporal resolution of $6 \mathrm{~h}$ and a horizontal resolution of $1.875^{\circ}$ latitude and longitude at 28 vertical levels.

MERRA is provided with a supplementary land surface data product adopting the Goddard Earth Observing System version 5.2, with 72 vertical levels produced by the National Aeronautics and Space Administration Global Modeling and Assimilation Office [43,62]. The MERRA-Land reanalysis dataset improves the accuracy of simulations for diurnal rainfall and radiation cycles [43]. Total surface precipitation and surface evaporation of MERRA had a horizontal resolution of $0.5^{\circ}$ latitude $\times 0.667^{\circ}$ longitude, with a three-dimensional variational analysis system covering the period from 1979 to 2018.

CFSR (retrospectively called the Climate Forecast System version 1) provides monthly data (64 vertical levels) with a horizontal resolution of $0.5^{\circ}$ and a temporal resolution of $6 \mathrm{~h}$ spanning 1979-2010 [44]. CFS version 2 (CFSv2) replaced the older version beginning in March 2011, and it uses a new data assimilation system to improve consistency between the initial and model states [63], covering the period from 2010 to 2018. Because daily and monthly data were not directly available in CFSv2, the 6-hourly products were accumulated to make a monthly resolution.

JRA-55, the second Japanese global atmospheric reanalysis dataset completed by the Japan Meteorological Agency, covers the period from 1958 to 2012 [45]. Compared with the Japanese 25-year Reanalysis dataset (nominally $1.125^{\circ}$ resolution and 40 vertical levels) [64], JRA-55 has a 
lower systematic model bias and a higher resolution $\left(0.5625^{\circ}\right.$ and 60 vertical levels). JRA-55 uses advanced assimilation techniques (a four-dimensional variational analysis system) and assimilates newly obtained observational data, such as atmospheric motion vector data and clear sky radiance data from the Geostationary Meteorological Satellite series and the Multi-functional Transport satellites operated by the Japan Meteorological Agency and from Meteosat operated by EUMETSAT [65].

\subsection{Methods}

To evaluate the performance of the reanalyses at monthly and seasonal timescales, we calculated the Pearson's correlation coefficients between monthly and seasonal changes in the snow accumulation measurements and simulations of the reanalyses (precipitation minus surface evaporation/sublimation). The correlations were considered significant at a $p$-value $\leq 0.05$, which was computed by transforming the correlation to create a $t$-statistic with $n-2$ degrees of freedom, where $n$ is the number of inputs. Monthly and seasonal snow accumulation measurements were summed up from daily measurements, and seasons were defined in the same manner as done by Reijmer and van den Broeke, as follows: summer encompasses December to February, autumn encompasses March to May, winter encompasses June to August, and spring encompasses September to November [7]. Additionally, we diagnosed the capture rate of the high precipitation events in the five reanalyses to further determine the relationship at the synoptic timescale between reanalyses and in situ observations. If the high precipitation events for reanalyses overlapped in time with $24 \mathrm{~h}$ of high accumulation events, the reanalyses were considered to have successfully captured these accumulation events.

High precipitation events at each station were determined by the prescribed local precipitation thresholds for the five reanalysis datasets. The threshold values were the 95th percentile (P95) of the total daily precipitation for each reanalysis dataset. These values were similar to the mean value added to twice the standard deviation used by Schlosser et al. (2010) [8]. The threshold values determined by standard deviations filtered out $4 \%$ of the daily precipitation events on all days but were smaller than the P95 value [13]. These threshold values were relatively high, ensuring that we only considered the precipitation events associated with synoptic systems [10]. The distributions of precipitation were typically non-Gaussian and did not follow the probability density function. Thus, percentile threshold was more suitable for high precipitation events, and the method ensured that the high accumulation events were induced by precipitation at a synoptic timescale $[8,13,37]$. Analogous to the high precipitation events in the reanalysis datasets, high accumulation events at each AWS were defined as those days when the changes in snow height were positive and greater than or equal to the 95 th percentile $(\geq \mathrm{P} 95)$ of all daily changes in snow height. Although it was generally difficult to distinguish all of the processes—such as snow drift, sublimation, and densification-in snow accumulation, the sparse in situ observations were indispensable for estimating the SMB at synoptic and seasonal timescales $[8,16]$.

\section{Results}

\subsection{Temporal and Spatial Changes in the In Situ Observations}

Snow accumulation is a complex process in Antarctica, involving snowfall, wind-driven sublimation, erosion, snow ablation, and compaction [47]. Thus, it remains difficult to accurately distinguish every postdislocation process $[7,18]$. Nevertheless, some processes were detected in the measured time series. However, the annual mass balance may even be zero or negative resulting in the absence of the annual accumulation layer on the ice core [7]. Additionally, the ice core properties are significantly impacted by high accumulation events during certain seasons [6,7]. Consequently, it is crucial to investigate synoptic accumulation events. Figure 1 shows the locations and annual mean $\mathrm{SMB}$ values of the 10 stations. These stations were distributed from the coast to the interior at altitudes between 188 (Evans Knoll) and 4048 m (Dome A). They covered the bulk of the Antarctic ice sheet, including the regions of east of Dronning Maud Land, Wilkes Land, and Marie Byrd Land. 
The annual SMB values ( $\mathrm{mm}$ water equivalent ( $\mathrm{mm}$ w.e.)/a) were the results of multiplying changes in snow height $(\mathrm{m})$ and snow density $(\mathrm{kg} / \mathrm{m})$ at the 10 stations. The average SMB for different regions varied markedly among regions from the coast to inland areas. Snow accumulation at inland stations (e.g., the South Pole, Dome A, and Panda) was $<40 \mathrm{~kg} \cdot \mathrm{m}^{2} / \mathrm{a}$, whereas snow accumulation was greater at coastal stations ( $>220 \mathrm{~kg} \cdot \mathrm{m}^{2} / \mathrm{a}$ at Dumont D'Urville). However, Evans Knoll $\left(\sim 40 \mathrm{~kg} \cdot \mathrm{m}^{2} / \mathrm{a}\right)$, which is located on the coast, showed relatively less annual snow accumulation and Relay Station had a negative annual accumulation $\left(<0 \mathrm{~kg} \cdot \mathrm{m}^{2} / \mathrm{a}\right)$. Although the two stations (D-47 and Dumont D'Urville) were located only $\sim 92 \mathrm{~km}$ apart, the difference in the amount of annual accumulation was considerable (mean, $100 \mathrm{~mm}$ w.e./a).

Seasonal variability is also important when estimating the SMB and dating ice core records. Figure 2 shows the monthly mean snow accumulation calculated from daily values accumulated by 10-min measurements at nine AWSs and half-monthly measurements at the South Pole station to demonstrate the annual cycle of snow accumulation. The South Pole station had lower snow accumulation in December and relatively higher accumulation from March to October. The frequency of the events was not estimated for the South Pole since it has only two measurements per month. In West Antarctica, Byrd showed a minimum average accumulation during spring months. However, the difference between maximum and minimum was not significant at Siple Dome. In contrast, the maximums at the East Antarctica stations were mainly distributed during spring and differed significantly from the other months. The exception was for Relay Station and D-47, which had obvious minimums during the summer months. The difference in interannual variability at Dumont D'Urville and D-47, which were close together, was significant, and this was probably caused by the different high snow accumulation events. All stations except the South Pole station had large interannual variations in snow accumulation, as indicated by the large errors (i.e., average standard deviation). Seasonality was unclear, probably as a result of the large interannual variability in snow accumulation due to the short temporal coverage of the data.

The monthly mean frequencies of high snow accumulation events for the different regions are shown in Figure 3. Three stations (Byrd, Evans Knoll, and Siple Dome) were located in West Antarctica, and all other stations were located in East Antarctica except the South Pole. In East Antarctica, such events were the least frequent during the summer months and more frequent during autumn and winter months. A similar seasonal cycle was found by Welker et al. (2014) for such events at DML [13]. However, occurrence frequencies of these events were relatively lower during autumn months in West Antarctica. To investigate the different distributions of such events, the monthly frequencies of events at nine stations were calculated, as shown in Figure 2. At all stations, occurrence frequencies of events showed regional similarities except at Panda and Evans Knoll. Additionally, the events showed insignificant relationships with snow accumulation at all stations at a monthly timescale.

Daily temperature and wind speed at two stations (Dome A and Eagle) were also analyzed. The average daily temperature when high accumulation events occurred was relatively lower at Dome A $\left(\sim 3^{\circ} \mathrm{C}\right)$ and Eagle $\left(\sim 6^{\circ} \mathrm{C}\right)$, respectively. The average wind speed when such events occurred at Dome A $(\sim 2.6 \mathrm{~m} / \mathrm{s})$ and Eagle $(\sim 4.4 \mathrm{~m} / \mathrm{s})$ did not change when compared with the average wind speed of all days $(\sim 2.5 \mathrm{~m} / \mathrm{s}$, and $\sim 4.5 \mathrm{~m} / \mathrm{s}$,). This observation suggests that such events were mainly caused by precipitation rather than snowdrift. 


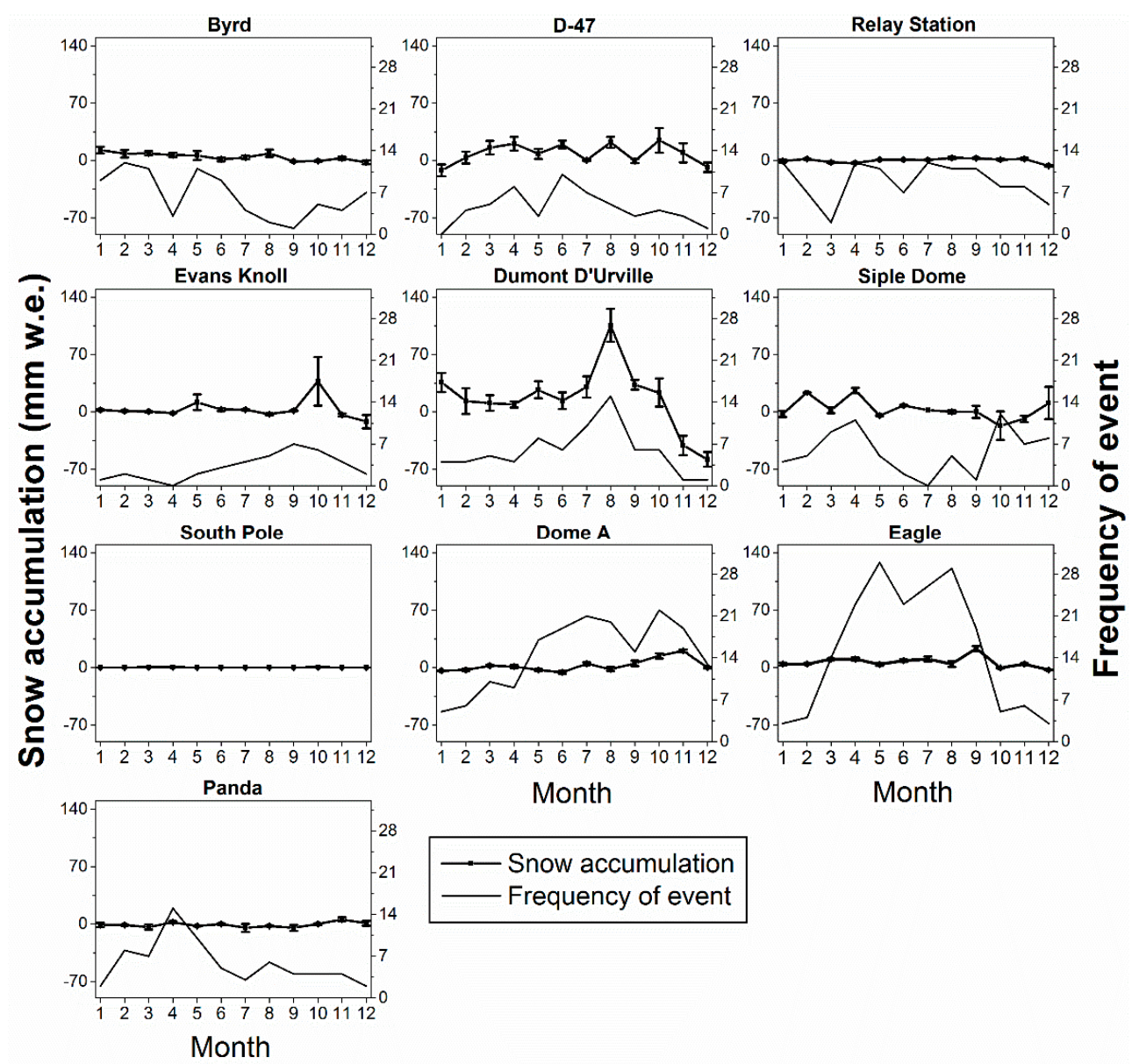

Figure 2. Seasonal variations in the annual average SMB at each station and the monthly frequencies of high accumulation events at nine stations. The left-hand axes show snow accumulation (mm w.e.) and the error bars denote the standard deviation of the mean values. The right-hand axes show the monthly frequencies of events.

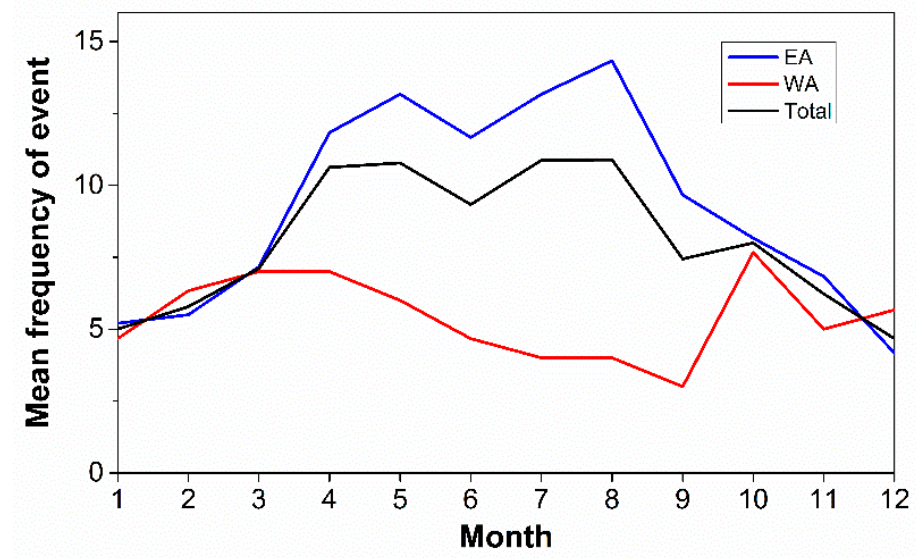

Figure 3. Monthly mean frequencies of high snow accumulation events in Antarctica (Total), East Antarctica (EA), and West Antarctica (WA).

\subsection{Comparison of Monthly and Seasonal Variability between the AWS Data and the Reanalysis Products}

To examine the performance of the reanalyses for the monthly changes in SMB, the correlations between the reanalyses and in situ observations were calculated using the time series of the monthly SMB results from AWSs and the reanalysis data. The five reanalysis datasets were positively correlated with the in situ observations at six stations, with correlation coefficients values varying from 0.24 
to 0.75 (Figure 4). In situ data were not related to five reanalyses for 4 of the 11 stations (i.e., D- 47 , Evans Knoll, Siple Dome, and Dome A). The NCEP2 dataset showed weaker relationships with the data from three stations (i.e., Dumont D'Urville, South Pole, and Panda), with relatively lower linear correlation coefficients. This was primarily the result of low spatial resolution and was consistent with previous studies on Antarctica [66,67]. The ERA-I dataset had a better monthly accuracy than the MERRA, CFSR, and JRA-55 datasets at five stations (i.e., Relay Station, Dumont D'Urville, South Pole, Eagle, and Panda). Although Byrd station was only correlated with the JRA-55 dataset, it had the highest correlation coefficient $(r=0.75)$. Only two stations (i.e., Dumont D'Urville and the South Pole) showed significant relationships with all five reanalysis datasets.

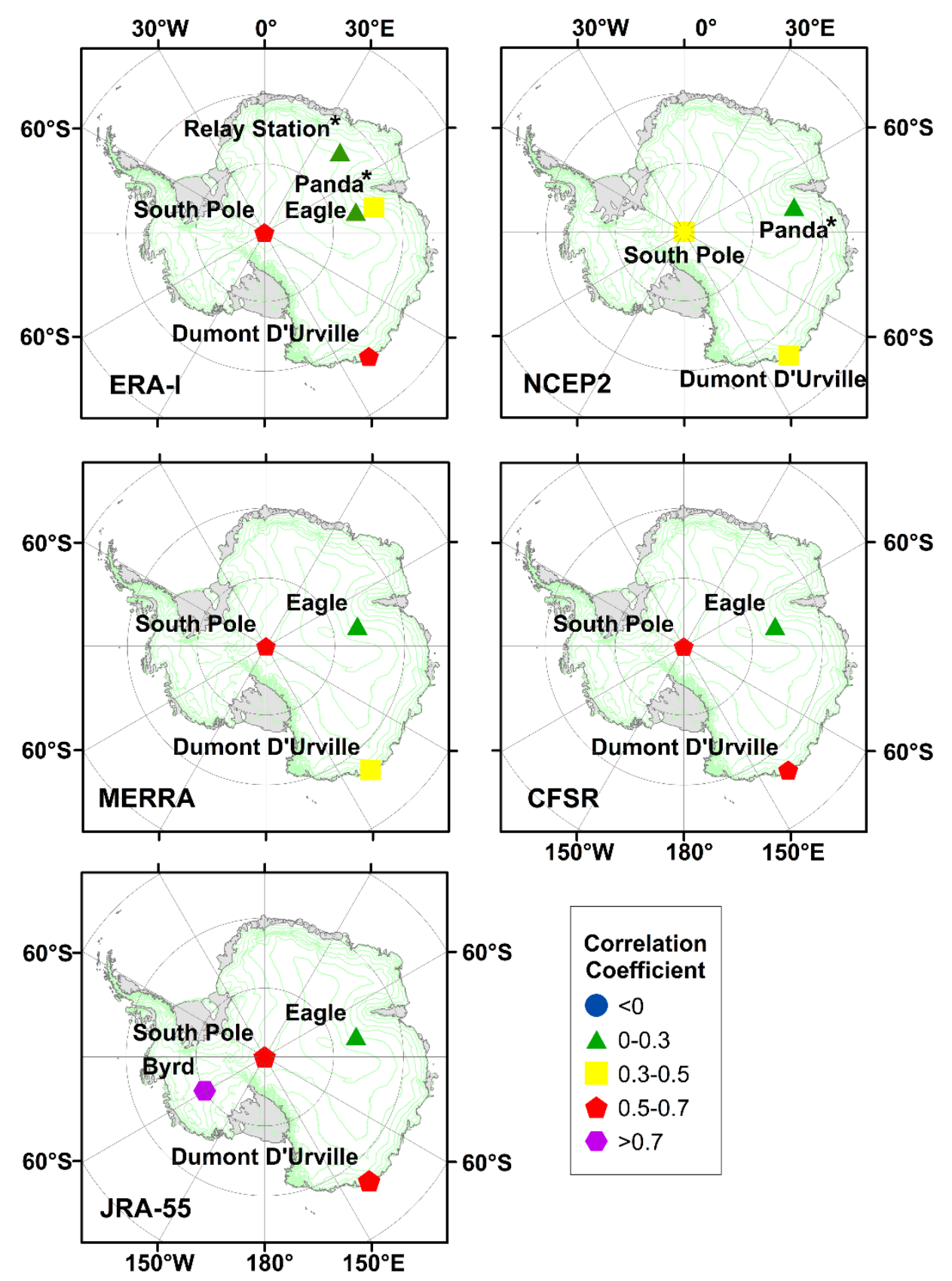

Figure 4. Maps show the monthly correlation coefficient values at the $95 \%$ significance level. Values marked with an asterisk are at the $90 \%$ significance level. AWSs with insignificant correlations are not shown in the figure. 
The accuracy of the seasonal simulation for the five reanalysis datasets was high at the South Pole and Dumont D'Urville stations (Figure 5). NCEP2, MERRA, and CFSR showed similar simulation precision at Dumont D'Urville and the South Pole. ERA-I and JRA-55 were correlated with three (Panda, Eagle, and Relay Station) and two (Eagle and Byrd) stations, respectively. In situ data from four stations (i.e., D-47, Evans Knoll, Siple Dome, and Dome A) which were correlated with the reanalyses at a monthly timescale showed insignificant relationships with five reanalyses at a seasonal timescale. Only JRA-55 was negatively correlated with the Eagle data. This negative correlation meant JRA-55 showed a decrease of accumulation that remained positive when the Eagle station had an increase of accumulation.

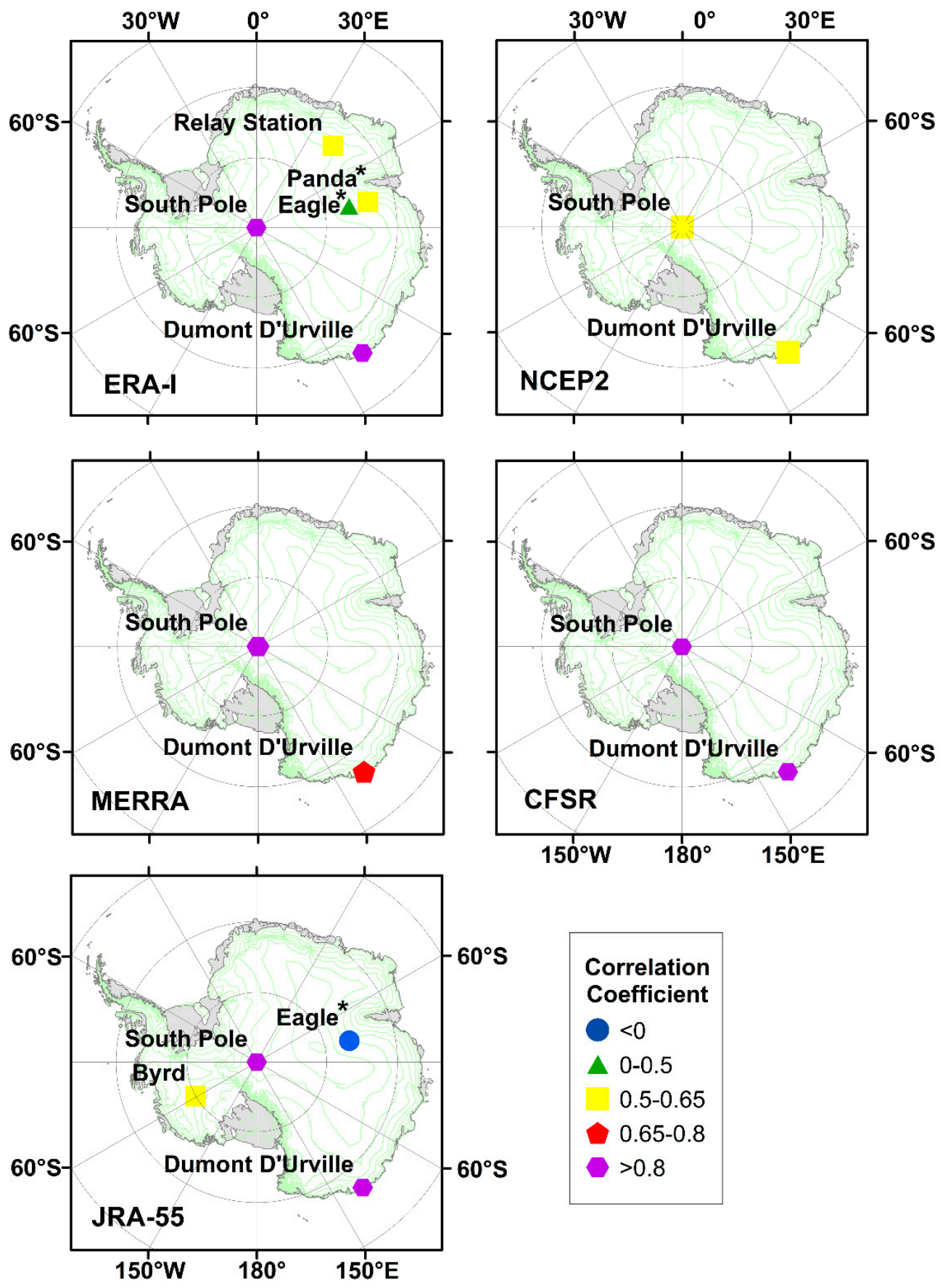

Figure 5. Maps show the seasonal correlation coefficient values at the $95 \%$ significance level. The values marked with an asterisk are at the $90 \%$ significance level. AWSs with insignificant correlations are not shown in the figure. 


\subsection{Comparison of Synoptic Variability between the AWS Data and the Reanalysis Datasets}

The distributions of the five reanalysis datasets indicated that high precipitation events $(\geq 95 \%$, defined in Section 2.3) resulted in an average of $36.3 \%-48.5 \%$ of the total mass gain for the nine AWSs. The overall difference in the precipitation distribution was relatively small at each station. Thus, only four stations are displayed exemplarily (Figure 6). The distributions of the precipitation in the ERA-I and CFSR datasets were similar, and this similarity also occurred in the MERRA and JRA-55 datasets for all stations. Another regularity was observed: if large snow accumulation events ( $\geq$ P95) formed a relatively large proportion of the total $(\geq 0.35)$, the MERRA and JRA-55 datasets produced better simulations than all of the others (e.g., Dumont D'Urville and Evans Knoll). The largest contribution of high precipitation events was simulated by JRA- 55 for all stations ( $48.5 \%$ of total precipitation). The daily precipitation values at Dome A of $>\mathrm{P} 95$ resulted in the largest percentage (73.4\%) of the total precipitation in the CFSR dataset. However, the high precipitation events of CFSR resulted in the smallest percentage of the total precipitation at Byrd and D-47.

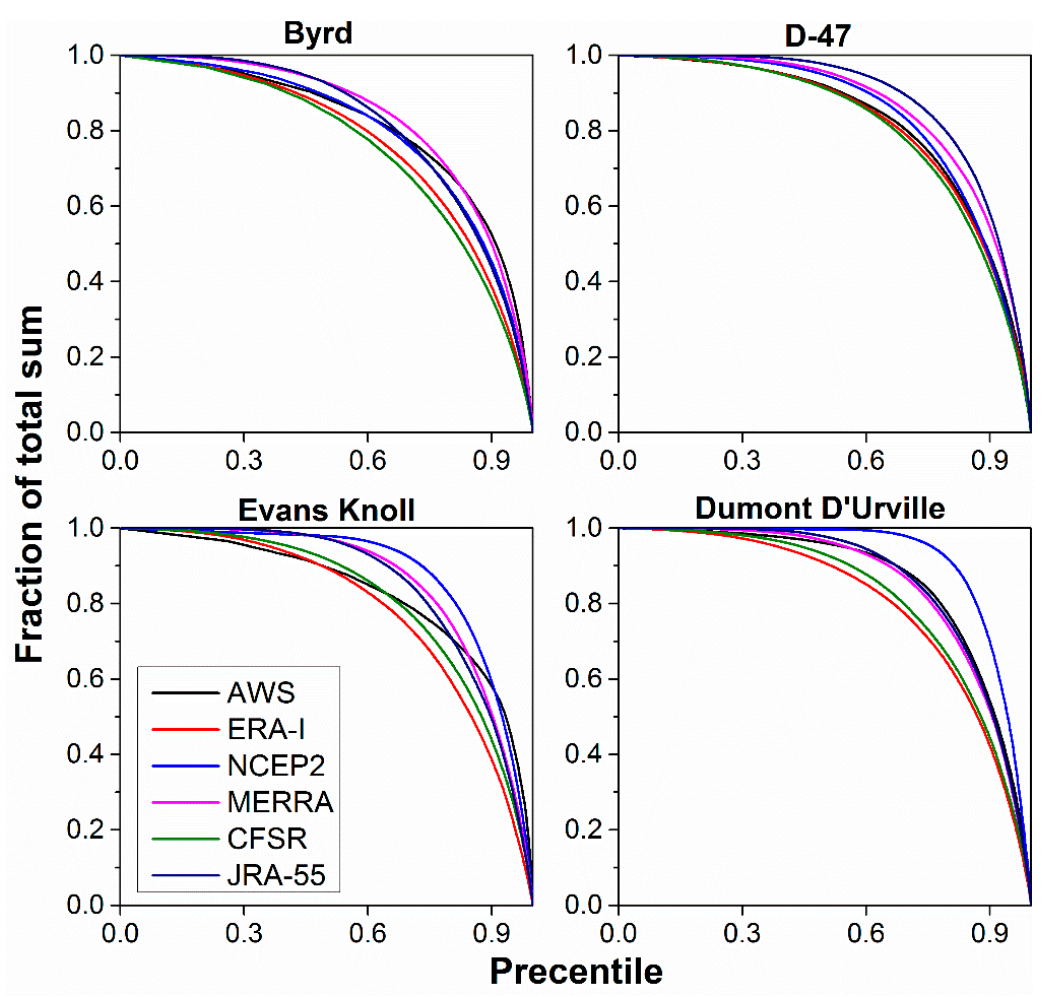

Figure 6. Distributions of the five reanalysis precipitation events and snow accumulation events for four stations. The $x$-axes show the precipitation/accumulation percentile, and the y-axes show the cumulated sum of all values above the respective percentile relative to the total sum.

High precipitation events were rare at each station, but they made a large contribution to snow accumulation. Thus, it is vital for the reanalyses to capture these events. Figure 7 shows the capture rate of the high precipitation events in the five reanalyses. Significant monthly or seasonal correlations between the in situ observations and the models had little impact on the capability of the reanalyses to capture high precipitation events. JRA-55 captured the most events in four stations (i.e., Byrd, D-47, Siple Dome, and Panda), even if it showed relatively weaker correlations with AWSs on monthly and seasonal timescales. CFSR also had high capture rates at three stations (i.e., Evans Knoll, Dome A, and Eagle). Although ERA-I had significant monthly and seasonal relationships with the AWSs, the capture rates were only higher at two stations (i.e., Relay Station and Dumont D'Urville). Dumont D'Urville not only showed significant monthly and seasonal correlations with reanalyses, but also had high capture rates for all of the five reanalyses. The reanalyses had better performance at the Dumont 
D'Urville at different timescales probably due to its location and aspect, allowing the reanalyses to make better simulations in this region. The mean capture rate of JRA- 55 at nine stations was more than $22 \%$. ERA-I and CFSR had similar mean capture rates (approximately $20 \%$ ) at all stations. NCEP2 and MERRA had lower capture rates of $14 \%$ and $17 \%$, respectively. SMB is controlled by many postdepositional processes, such as surface sublimation, wind deposition/erosion, and sublimation. Such processes are not fully considered in the reanalyses and can impact the accuracy of the modeled SMB. Additionally, the frequency of high precipitation events was relatively low. Thus, the capture rates of the reanalyses were acceptable to some extent.

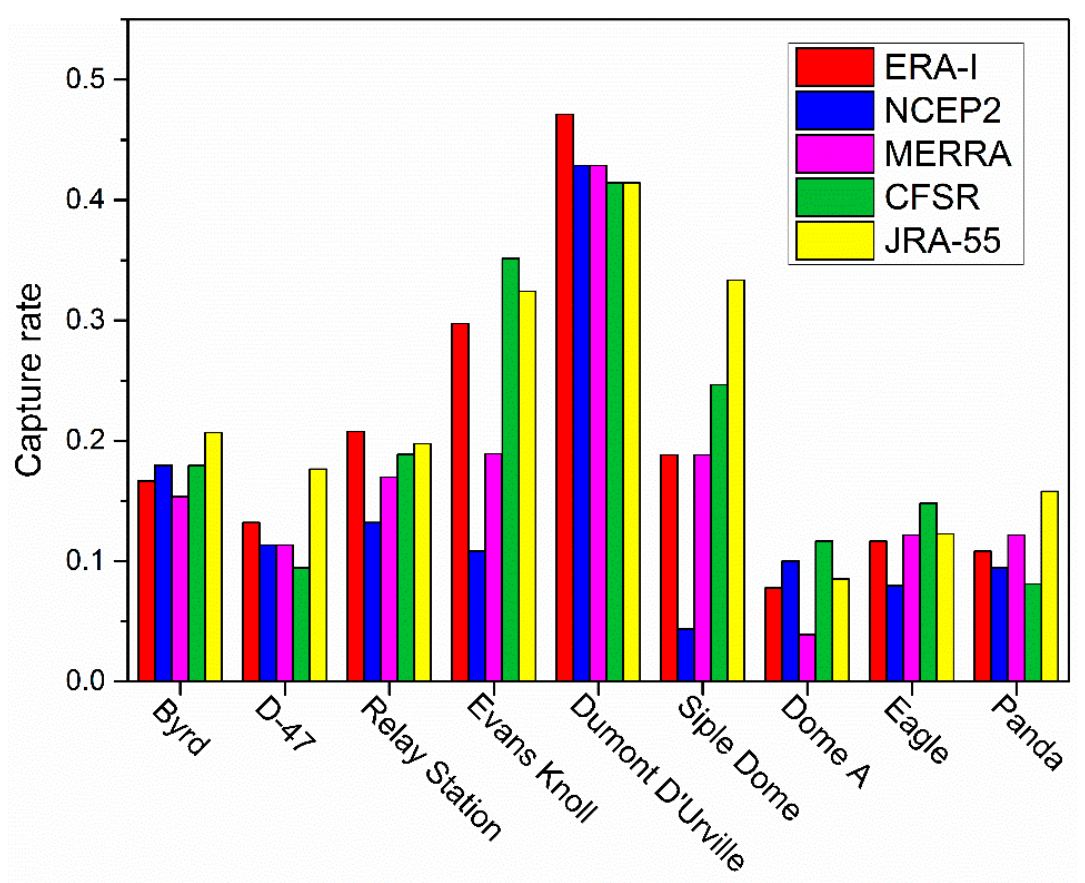

Figure 7. The capture rate of the high precipitation events for the five reanalyses.

\section{Conclusions}

SMB values derived from in situ observations provide valuable information to determine its temporal and spatial variability in different regions in Antarctica. In situ observations are of particular importance given the Antarctic wet coastal regions and dry interiors and can also be used to evaluate variability in the simulated SMB at a regional scale. The average SMB for different regions exhibited marked variations from the coast to inland areas. However, the general trend of decreasing snow accumulation with increasing distance from the coast was not true at every station (e.g., Evans Knoll and Relay Station). Different water vapor sources could impact precipitation at the coastal stations (e.g., difference at the Evans Knoll and Dumont D'Urville). The Relay Station was located at a high altitude with less moisture from the ocean, probably resulting in reduced accumulation. D-47 was located at a higher elevation and showed an obviously different SMB compared with Dumont D'Urville. This may be due to increasing elevation and differences in the orientation and size of the surface slope, which could lead to large differences in accumulation over small distances $[68,69]$. These stations were located at or close to escarpment regions or mountainous areas, which has a great influence on cyclonic systems, wind erosion, and the deposition of snow [68,70]. The SMB trends were not statistically significant probably due to the large interannual variability and limited time coverage, except for the South Pole station, which had long-term annual SMB observations due to the availability of associated logistical support.

It remains to be a great challenge for the reanalyses to simulate the meteorological parameters at the high southern latitudes [28]. In situ observations were useful to evaluate the performance of the reanalyses at a regional scale. This study contrasted and evaluated five global reanalyses 
(i.e., ERA-I, NCEP2, MERRA, CFSR, and JRA-55) in Antarctica based on in situ observations from 1983 to 2015. The simulated accuracy of the five reanalysis datasets was estimated based on synoptic, monthly, and intra-annual timescales. The correlations between the reanalysis datasets and the in situ observations depended on the geographical location of the stations. The performance of the reanalysis datasets at different timescales was better in the coastal areas of Antarctica than in the interior regions. The five reanalysis datasets (i.e., ERA, NCEP2, MERRA, CFSR, and JRA-55) revealed significant monthly and seasonal correlations with 6 of the 10 AWSs. The ability of the five reanalysis datasets to simulate in situ observations varied largely for different regions and timescales. Except for NCEP2, the other four reanalysis datasets, particularly ERA-I and JRA-55, had similar and good monthly and seasonal correlations with the in situ observations. Such correlations were similar in CFSR and MERRA. Only two stations (i.e., Dumont D'Urville and South Pole) showed significant seasonal correlations with the five reanalysis datasets. Four stations (i.e., D-47, Evans Knoll, Siple, and Dome A) were not related with the models, probably because of the large interannual variability and the short time period of measurement.

High precipitation events were rare at each station, but they resulted in an average of $36.3 \%-48.5 \%$ of the total cumulated precipitation for the nine AWSs. High accumulation events made larger contributions to the total SMB ( $>35 \%$ ) at the West Antarctic stations (e.g., Evans Knoll ( $>45 \%$ ) and Byrd $(>37 \%))$, probably caused by the larger ablation that occurred compared with East Antarctica. The frequencies of events were small during the summer months (e.g., D-47, Evans Knoll, and Eagle). The other components (i.e., ablation, compaction, or sublimation) may be more relevant than precipitation and impacted the simulation accuracy of the reanalyses. It is important to assimilate more remote sensing data of such parameters in the reanalyses. Significant monthly or seasonal correlations between in situ observations and the models showed little impact on the capability of the reanalyses to capture high precipitation events. NCEP2 showed the lowest simulation precision with its coarse spatial resolution. Although ERA-I showed the best simulation at monthly and seasonal timescales, JRA-55 captured the greatest number of high precipitation events compared to the other four reanalyses at four stations (i.e., Byrd, D-47, Siple Dome, and Panda). At three stations (i.e., Evans Knoll, Dome A, and Eagle), CFSR also captured more events than ERA-I. In addition, the mean capture rate of JRA-55 at nine stations was the highest $(\sim 22 \%)$. This result suggests that JRA-55 may provide better simulations for such events than ERA-I at a synoptic timescale.

The overestimate of SMB in some coastal regions of Antarctica (i.e., Evans Knoll and D-47) is a common problem of atmospheric models, associated with the artificial diffusion-enhanced moisture transport along model levels which can result in uphill transport of moisture [71-73]. The difference between model and surface elevation also causes simulated errors in areas with steep topography [30]. An acceleration in ice mass loss has been detected in West Antarctica, but the mass loss is relatively small on Wilkes Land [3,74]. However, the reanalyses lacked some complex parameterizations for the Antarctic snowpack (i.e., sublimation of drifting snow particles and horizontal snow transport). This probably led to the low simulation precision of the reanalyses in West Antarctica. Dumont D'Urville was correlated with the reanalyses at all timescales probably because it has few of these problems.

It seemed that the coarse spatial resolution could also affect the simulation precision on monthly and synoptic timescales; that is, only a few significant correlations were found between the in situ observations and NECP2. The better monthly simulations of the reanalyses were mainly distributed in East Antarctica and only JRA-55 was correlated with Byrd in West Antarctica on monthly and seasonal timescales. JRA-55 and CFSR captured a greater number of high accumulation events at two stations (i.e., Siple Dome and Byrd) in West Antarctica, and the five reanalyses captured fewer events for the Elizabeth Land (e.g., Dome A, Eagle, and Panda).

The performance of the reanalyses was largely improved by advanced assimilation techniques, such as the four-dimensional variational analysis system. ERA-I, CFSR, and JRA-55 showed better simulated results with this new system. Although MERRA had more vertical levels, it had fewer 
significant relationships with the in situ observations using the old system. More observational data need to be assimilated into the reanalyses; for example, JRA-55, with newly obtained observational data, showed better simulations at a synoptic timescale. It has been reported that snow precipitation is fairly homogeneous at a spatial scale of hundreds of $\mathrm{km}^{2}$ over Antarctica [75], but small-scale features in atmospheric circulation, particularly in precipitation, had impacts on snow accumulation, particularly in rugged areas. In addition, snow accumulation varies widely between years in Antarctica. Thus, it would be better to examine the performance of reanalyses with more measurements from different stations covering the greatest amount of Antarctica.

A longer time series of snow accumulation measurements is also needed owing to the sparseness of these events at each station. However, continuous measurements from AWSs are limited in Antarctica, and measurements are generally not posted publicly. More AWSs are being set up in Antarctica, so more in situ observations with a longer time series could be used to help improve the performance of the reanalyses. Utilization of the reanalyses requires great caution in all of Antarctica, as the simulation accuracies of the reanalyses were distinct in different regions. The discrepancy of each reanalysis emphasizes the necessity of improving the reanalysis simulations of Antarctic precipitation for a correct interpretation of ice cores and a better understanding of the sea level rise contributed by the Antarctic ice sheet.

Author Contributions: Y.L. wrote the original draft of the manuscript. W.H. reviewed and edited the draft. F.L. acquired funding.

Funding: This research was funded by the National Key R\&D Program of China, grant number 2017YFA0603102, and the Natural Science Foundation of China, grant number 41531069.

Acknowledgments: We thank two anonymous reviewers and editors for their valuable comments and suggestions. The authors also appreciate use of the ERA-Interim data provided by the European Centre for Medium-Range Weather Forecasts; the use of NCEP2 data provided by the NOAA/OAR/ESRL PSD, Boulder, Colorado, USA; the use of MERRA data provided by the American National Aeronautics and Space Administration Global Modeling and Assimilation Office; the use of CFSR data provided by the National Center for Atmospheric Research, Computational and Information Systems Laboratory; and use of the JRA-55 data provided by the Japan Meteorological Agency.

Conflicts of Interest: The authors declare no conflict of interest.

\section{References}

1. Forsberg, R.; Sørensen, L.; Simonsen, S. Greenland and Antarctica Ice Sheet Mass Changes and Effects on Global Sea Level. Surv. Geophys. 2017, 38, 89-104. [CrossRef]

2. Stocker, T.F.; Qin, D.; Plattner, G.K.; Tignor, M.M.B.; Allen, S.K.; Nauels, A.; Xia, Y.; Midgley, P.M. IPCC Climate Change 2013: The Physical Science Basis. Contribution of Working Group I to the Fifth Assessment Report of the Intergovernmental Panel on Climate Change; Cambridge University Press: Cambridge, UK, 2013; p. 1535.

3. Rignot, E.; Velicogna, I.; van den Broeke, M.R.; Monaghan, A.; Lenaerts, J.T.M. Acceleration of the contribution of the Greenland and Antarctic ice sheets to sea level rise. Geophys. Res. Lett. 2011, 38, L05503. [CrossRef]

4. Shepherd, A.; Lvins, E.R.; Geruo, A.G.; Barletta, V.R.; Bettadpur, M.J.; Bettadpur, S.; Briggs, K.H. A reconciled estimate of ice-sheet mass balance. Science 2012, 338, 1183-1189. [CrossRef] [PubMed]

5. Zwally, H.J.; Li, J.; Robbins, J.W.; Saba, J.L.; Yi, D.H.; Brenner, A.C. Mass gains of the Antarctic ice sheet exceed losses. J. Glaciol. 2015, 61, 1019-1036. [CrossRef]

6. King, J.C.; Turner, J. Antarctic Meteorology and Climatology; Cambridge University Press: Cambridge, UK, 1997.

7. Reijmer, C.H.; van den Broeke, M.R. Temporal and spatial variability of the surface mass balance in Dronning Maud Land, Antarctica. J. Glaciol. 2003, 49, 512-520. [CrossRef]

8. Schlosser, E.; Manning, K.W.; Powers, J.G.; Duda, M.G.; Birnbaum, G.; Fujita, K. Characteristics of high-precipitation events in Dronning Maud Land, Antarctica. J. Geophys. Res. 2010, 115, D14107. [CrossRef]

9. Noone, D.; Turner, J.; Mulvaney, R. Atmospheric signals and characteristics of accumulation in Dronning Maud Land, Antarctica. J. Geophys. Res. 1999, 104, 191-211. [CrossRef] 
10. Jouzel, J.; Alley, R.B.; Cuffey, K.M.; Dansgaard, W.; Grootes, P.; Hoffmann, G.; Johnsen, S.F.; Koster, R.D.; Peel, D.; Shuman, A.; et al. Validity of temperature reconstruction from water isotopes in ice cores. J. Geophys. Res. 1997, 102, 26471-26487. [CrossRef]

11. Jouzel, J.; Vimeux, F.; Caillon, N.; Delaygue, G.; Hoffmann, G.; Masson-Delmotte, G.V.; Parrenin, F. Magnitude of isotope/temperature scaling for interpretation of central Antarctic ice cores. J. Geophys. Res. 2003, 108, 4361. [CrossRef]

12. Schlosser, E. Effects of seasonal variability of accumulation on yearly mean $\delta^{18} \mathrm{O}$ values in Antarctic snow. J. Glaciol. 1999, 45, 463-468. [CrossRef]

13. Welker, C.; Martius, O.; Froidevaux, P.; Reijmer, C.H.; Fischer, H. A climatological analysis of high-precipitation events in Dronning Maud Land, Antarctica, and associated large-scale atmospheric conditions. J. Geophys. Res. 2014, 119, 11932-11954. [CrossRef]

14. Bromwich, D.H. Snowfall in high southern latitudes. Rev. Geophys. 1988, 26, 149-168. [CrossRef]

15. Rotschky, G.; Holmlund, P.; Isaksson, E.; Mulvaney, R.; Oerter, H.; van den Broeke, M.R.; Winther, J.G. A new surface accumulation map for western Dronning Maud Land, Antarctica, from interpolation of point measurements. J. Glaciol. 2007, 53, 385-398. [CrossRef]

16. Schlosser, E.; Duda, M.G.; Powers, J.G.; Manning, K.W. The precipitation regime of Dronning Maud Land, Antarctica, derived from Antarctic Mesoscale Prediction System (AMPS) archive data. J. Geophys. Res. 2008, 113, D24108. [CrossRef]

17. Gorodetskaya, I.V.; Kneifel, S.; Maahn, M.; Van Tricht, K.; Thiery, W.; Schween, J.H.; Mangold, A.; Crewell, S.; van Lipzig, N.P.M. Cloud and precipitation properties from ground-based remote-sensing instruments in East Antarctica. Cryosphere 2015, 9, 285-304. [CrossRef]

18. Souverijns, N.; Gossart, A.; Gorodetskaya, I.V.; Lhermitte, S.; Mangold, A.; Laffineur, Q.; Delcloo, A.; Van Lipzig, N.P.M. How does the ice sheet surface mass balance relate to snowfall? Insights from a ground-based precipitation radar in East Antarctica. Cryosphere 2018, 12, 1987-2003. [CrossRef]

19. Bromwich, D.H.; Guo, Z.; Bai, L.; Chen, Q. Modeled Antarctic Precipitation-Part I: Spatial and Temporal Variability. J. Clim. 2004, 2004, 427-447. [CrossRef]

20. Palerme, C.; Kay, J.E.; Genthon, C.; L’Ecuyer, T.; Wood, N.B.; Claud, C. How much snow falls on the Antarctic ice sheet? Cryosphere 2014, 8, 1279-1304. [CrossRef]

21. Boening, C.; Lebsock, M.; Landerer, F.; Stephens, G. Snowfall-driven mass change on the East Antarctic ice sheet. Geophys. Res. Lett. 2012, 39, L21501. [CrossRef]

22. Palerme, C.; Genthon, C.; Claud, C.; Kay, J.E.; Wood, N.B.; L'Ecuyer, T. Evaluation of current and projected Antarctic precipitation in CMIP5 models. Clim. Dyn. 2016, 48, 1-15. [CrossRef]

23. Monaghan, A.J.; Bromwich, D.H.; Fogt, R.L.; Wang, S.H.; Mayewski, P.A.; Dixon, D.A.; Ekaykin, A.; Frezzotti, M.; Goodwin, I.; Isaksson, E.; et al. Insignificant change in Antarctic snowfall since the International Geophysical Year. Science 2006, 313, 827-831. [CrossRef] [PubMed]

24. Krinner, G.; Magand, O.; Simmonds, I.; Genthon, C.; Dufresne, J.L. Simulated Antarctic precipitation and surface mass balance at the end of twentieth and twenty-first centuries. Clim. Dyn. 2007, 28, 215-230. [CrossRef]

25. Marshall, G.J. On the annual and semi-annual cycles of precipitation across Antarctica. Int. J. Climatol. 2009, 29, 2298-2308. [CrossRef]

26. Bromwich, D.H.; Nicolas, J.P.; Monaghan, A.J. An assessment of precipitation changes over Antarctica and the Southern Ocean since 1989 in contemporary global reanalyses. J. Clim. 2011, 24, 4189-4209. [CrossRef]

27. Trenberth, K.E.; Fasullo, J.T.; Mackaro, J. Atmospheric moisture transports from ocean to land and global energy flows in reanalyses. J. Clim. 2010, 24, 4907-4924. [CrossRef]

28. Bromwich, D.H.; Steinhoff, D.F.; Simmonds, I.; Keay, K.; Fogt, R.L. Climatological aspects of cyclogenesis near Adélie Land, Antarctica. Tellus 2011, 63, 921-938. [CrossRef]

29. Bosilovich, M.G.; Robertson, F.R.; Chen, J.Y. Global energy and water budgets in MERRA. J. Clim. 2011, 24, 5721-5739. [CrossRef]

30. Agosta, C.; Favier, V.; Genthon, C.; Gallée, H.; Krinner, G.; Lenaerts, J.T.M.; van den Broeke, M.R. A 40-year accumulation dataset for Adelie Land, Antarctica and its application for model validation. Clim. Dyn. 2012, 38, 75-86. [CrossRef] 
31. Wang, Y.T.; Hou, S.G.; Sun, W.J.; Lenaerts, J.T.M.; van den Broeke, M.R.; van Wessem, J.M. Recent surface mass balance from Syowa Station to Dome F, East Antarctica: Comparison of field observations, atmospheric reanalyses, and a regional atmospheric climate model. Clim. Dyn. 2015, 45, 2885-2899. [CrossRef]

32. Medley, B.; Joughin, I.; Das, S.B.; Steig, E.J.; Conway, H.; Gogineni, S.; Criscitiello, A.S.; McConnell, J.R.; Smith, B.E.; van den Broeke, M.R.; et al. Airborne-radar and ice-core observations of annual snow accumulation over Thwaites Glacier, West Antarctica confirm the spatiotemporal variability of global and regional atmospheric models. Geophys. Res. Lett. 2013, 40, 3649-3654. [CrossRef]

33. Sinisalo, A.; Anschütz, H.; Aasen, A.T.; Langley, K.; von Deschwanden, A.; Kohler, J.; Matsuoka, K.; Hamran, S.E.; Øyan, M.J.; Schlosser, E.; et al. Surface mass balance on Fim-bul ice shelf, East Antarctica: Comparison of field measurements and large-scale studies. J. Geophys. Res. 2013, 118, 11625-11635. [CrossRef]

34. Arthern, R.J.; Winebrenner, D.P.; Vaughan, D.G. Antarctic snow accumulation mapped using polarization of 4.3-cm wavelength microwave emission. J. Geophys. Res. 2006, 111, D06107. [CrossRef]

35. Van de Berg, M.J.; van den Broeke, M.R.; Reijmer, C.H.; van Meijgaard, E. Characteristics of the Antarctic surface mass balance, 1958-2002, using a regional atmospheric climate model. Ann. Glaciol. 2005, 41, 97-104. [CrossRef]

36. Wang, Y.; Ding, M.; van Wessem, J.M.; Schlosser, E.; Altnau, S.; van den Broeke, M.R.; Lenaerts, J.M.; Thomas, E.R.; Isaksson, E.; Wang, J.; et al. A Comparison of Antarctic Ice Sheet Surface Mass Balance from Atmospheric Climate Models and In Situ Observations. J. Clim. 2016, 29, 5317-5336. [CrossRef]

37. Schlosser, E.; Powers, J.G.; Duda, M.G.; Manning, K.W.; Reijmer, C.H.; van den Broeke, M.R. An extreme precipitation event in Dronning Maud Land, Antarctica: A case study with the Antarctic Mesoscale Prediction System. Polar Res. 2010, 29, 330-344. [CrossRef]

38. Schlosser, E.; Dittmann, A.; Stenni, B.; Powers, J.G.; Manning, K.W.; Masson-Delmotte, V.; Valt, M.; Gagnati, A.; Grigioni, P.; Scarchilli, C. The influence of the synoptic regime on stable water isotopes in precipitation at Dome C, East Antarctica. Cryosphere 2011, 11, 2345-2361. [CrossRef]

39. Cohen, L.; Dean, S. Snow on the Ross Ice Shelf: Comparison of reanalyses and observations from automatic weather stations. Cryosphere 2013, 7, 1399-1410. [CrossRef]

40. Dittmann, A.; Schlosser, E.; Masson-Delmotte, V.; Powers, J.G.; Manning, K.W.; Werner, M.; Fujita, K. Precipitation regime and stable isotopes at Dome Fuji, East Antarctica. Atmos. Chem. Phys. 2016, 16, 6883-6900. [CrossRef]

41. Dee, D.P.; Uppala, S.M.; Simmons, A.J.; Berrisford, P.; Kobayashi, P.; Andrae, S.; Alonso-Balmaseda, U.; Balsamo, M.; Bauer, G.; Bechtold, P.; et al. The ERA-Interim reanalysis: Configuration and performance of the data assimilation system. Q. J. R. Meteorol. Soc. 2011, 137, 553-597. [CrossRef]

42. Kanamitsu, M.; Ebisuzaki, W.; Woollen, J.; Yang, S.K.; Hnilo, J.J.; Fiorino, M.; Potter, G.L. NCEP-DOE AMIP-II reanalysis (R-2). Bull. Am. Meteorol. Soc. 2002, 83, 1631-1643. [CrossRef]

43. Rienecker, M.M.; Suarez, M.J.; Gelaro, R.; Toding, R.; Bacmeister, J.T. MERRA: NASA's Modern-Era Retrospective Analysis for Research and Applications. J. Clim. 2011, 24, 3624-3648. [CrossRef]

44. Saha, S.; Moorthi, S.; Pan, H.L.; Wu, X.; Wang, J.; Nadiga, S.; Tripp, P.; Kistler, R.; Woollen, J.; Behringer, D.; et al. The NCEP Climate Forecast System Reanalysis. Bull. Am. Meteorol. Soc. 2010, 91, 1015-1057. [CrossRef]

45. Ebita, A.; Kobayashi, S.; Ota, Y.; Moriya, M.; Kumabe, R.; Onogi, K.; Harada, Y.; Yasui, S.; Miyaoka, K.; Takahashi, K.; et al. The Japanese 55-year Reanalysis "JRA-55": An interim report. SOLA 2011, 7, 149-152. [CrossRef]

46. Schlosser, E.; Stenni, B.; Valt, M.; Cagnati, A.; Powers, J.G.; Manning, K.W.; Raphael, M.; Duda, M.G. Precipitation and synoptic regime in two extreme years 2009 and 2010 at Dome C, Antarctica-Implications for ice core interpretation. Atmos. Chem. Phys. 2016, 16, 4757-4770. [CrossRef]

47. Maahn, M.; Kollias, P. Improved Micro Rain Radar snow measurements using Doppler spectra post-processing. Atmos. Meas. Tech. 2012, 5, 2661-2673. [CrossRef]

48. Souverijns, N.; Gossart, A.; Lhermitte, S.; Gorodetskaya, I.V.; Kneifel, S.; Maahn, M.; Bliven, F.L.; van Lipzig, N.P.M. Estimating radar reflectivity—Snowfall rate relationships and their uncertainties over antarctica by combining disdrometer and radar observations. Atmos. Res. 2017, 196, 211-223. [CrossRef]

49. Brandes, E.A.; Ikeda, K.; Zhang, G.; Schönhuber, M.; Rasmussen, R.M. A statistical and physical description of hydrometeor distributions in Colorado snowstorms using a video disdrometer. J. Appl. Meteorol. Climatol. 2007, 46, 634-650. [CrossRef] 
50. Wood, N.B.; L'Ecuyer, T.S.; Bliven, F.L.; Stephens, G.L. Characterization of video disdrometer uncertainties and impacts on estimates of snowfall rate and radar reflectivity. Atmos. Meas. Tech. 2013, 6, 3635-3648. [CrossRef]

51. Grazioli, J.; Genthon, C.; Boudevillain, B.; Duran-Alarcon, C.; Del Guasta, M.; Madeleine, J.B.; Berne, A. Measurements of precipitation in Dumont D'Urville, Adélie Land, East Antarctica. Cryosphere 2017, 11, 1797-1811. [CrossRef]

52. Brazenec, W.A.; Doesken, N.J.; Kelvin, T. An evaluation of two ultrasonic snow depth sensors for potential use at automated surface weather observing sites. In Proceedings of the 13th Symposium on Meteorological Observations and Instrumentation, American Meteorological Society, Savannah, GA, USA, 19-23 June 2005.

53. Fountain, A.G.; Nylen, T.H.; Monaghan, A.; Basagic, H.J.; Bromwich, D. Snow in the McMurdo Dry Valleys, Antarctica. Int. J. Climatol. 2010, 30, 633-642. [CrossRef]

54. Reijmer, C.H.; van den Broeke, M.R. Moisture sources of precipitation in western Dronning Maud Land, Antarctica. Antarct. Sci. 2001, 13, 210-220. [CrossRef]

55. Lazzara, M.A.; Weidner, G.A.; Keller, L.M.; Thom, J.E.; Cassano, J.J. Antarctic Automatic Weather Station Program: 30 years of polar observations. Bull. Am. Meteorol. Soc. 2012, 93, 1519-1537. [CrossRef]

56. Fountain, A.G.; Nylen, T.H.; Macclune, K.L.; Dana, G.L. Glacier mass balances (1993-2001), Taylor Valley, McMurdo Dry Valleys, Antarctica. J. Glaciol. 2006, 52, 451-462. [CrossRef]

57. Kameda, T.; Motoyama, H.; Fujita, S.; Takahashi, S. Temporal and spatial variability of surface mass balance at Dome Fuji, East Antarctica, by the stake method from 1995 to 2006. J. Glaciol. 2008, 54, 107-116. [CrossRef]

58. Berrisford, P.; Dee, D.; Fielding, K.; Fuentes, M.; Kallberg, P.; Kobayashi, S.; Uppala, S.M. The ERA-Interim Archive; Era Report; ECMWF: Reading, UK, 2009.

59. Simmons, A.J.; Willett, K.M.; Jones, P.D.; Thorne, P.W.; Dee, P.D. Low-frequency variations in surface atmospheric humidity, temperature, and precipitation: Inferences from reanalyses and monthly gridded observational data sets. J. Geophys. Res. 2010, 115, D01110. [CrossRef]

60. Ma, L.; Zhang, T.; Li, Q.; Frauenfeld, O.W.; Qin, D. Correction to “Evaluation of ERA-40, NCEP-1, and NCEP-2 reanalysis air temperatures with ground-based measurements in China. J. Geophys. Res. 2008, 113, 18199. [CrossRef]

61. Kanamitsu, H.; Kanamaru, M. Fifty-Seven-Year California Reanalysis Downscaling at 10 km (CaRD10). Part II: Comparison with North American Regional Reanalysis. J. Clim. 2007, 20, 5572-5592. [CrossRef]

62. Bosilovich, M.G.; Chen, J.; Robertson, F.R.; Adler, R.F. Evaluation of global precipitation in reanalyses. J. Appl. Meteorol. Clim. 2008, 47, 2279-2299. [CrossRef]

63. Saha, S.; Moorthi, S.; Wu, X.; Wang, J.; Wang, W.; Zhang, Q.; van den Dool, H.M. The NCEP Climate Forecast System Version 2. J. Clim. 2014, 27, 2185-2208. [CrossRef]

64. Onogi, K.; Tsutsui, J.; Koide, H.; Sakamoto, M.; Kobayashi, S.; Hatsushika, H.; Matsumoto, T.; Yamazaki, N.; Kamahori, H.; Takahashi, K.; et al. The JRA-25 Reanalysis. J. Meteorol. Soc. Jpn. 2007, 85, 369-432. [CrossRef]

65. Kobayashi, S.; Ota, Y.; Harada, Y.; Ebita, A.; Moraya, M.; Onoda, H.; Onogi, K.; Kamahori, H.; Kobayashi, C.; Endo, H.; et al. The JRA-55 Reanalysis: General specifications and basic characteristics. J. Meteorol. Soc. Jpn. 2015, 93, 5-48. [CrossRef]

66. Boccara, G.; Hertzog, A.; Basdevant, C.; Vial, F. Accuracy of NCEP/NCAR reanalyses and ECMWF analyses in the lower stratosphere over Antarctica in 2005. J. Geophys. Res. 2008, 113, 2739-2740. [CrossRef]

67. Bromwich, D.H.; Cullather, R.I.; Grumbine, R.W. An Assessment of the NCEP Operational Global Spectral Model Forecasts and Analyses for Antarctica during FROST. Weather Forecast. 1999, 14, 835-850. [CrossRef]

68. Melvold, K.; Hagen, J.O.; Pinglot, J.F.; Gundestrup, N. Large spatial variation in accumulation rate in Jutulstraumen ice stream, Dronning Maud Land, Antarctica. Ann. Glaciol. 1998, 27, 231-238. [CrossRef]

69. Richardson, C.; Holmlund, P. Spatial variability at shallow snowlayer depths in central Dronning Maud Land, East Antarctica. Ann. Glaciol. 1999, 29, 10-16. [CrossRef]

70. van den Broeke, M.R.; Winther, J.G.; Elisabeth, I.; Pinglot, J.F.; Karlof, L.; Eiken, T.; Conrads, L. Climate variables along a traverse line in Dronning Maud Land, East Antarctica. J. Glaciol. 1999, 45, $295-302$. [CrossRef] 
71. van Lipzig, N.P.M.; van den Broeke, M.R. A model study on the relation between atmospheric boundary-layer dynamics and poleward atmospheric moisture transport in Antarctica. Tellus 2002, 54A, 497-511. [CrossRef]

72. Lenderink, G.; van den Hurk, B.; van Meijgaard, E.; van Ulden, A.; Cuijpers, H. Simulation of Present-Day Climate in RACMO2: First Results and Model Developments; KNMI Technical Report; KNMI: De Bilt, The Netherlands, 2003; Volume 252, 24p.

73. Van de Berg, W.J.; van den Broeke, M.R.; Reijmer, C.; van Meijgaard, E. Reassessment of the Antarctic surface mass balance using calibrated output of a regional atmospheric climate model. J. Geophys. Res. 2006, 111, D11104. [CrossRef]

74. Velicogna, I.; Sutterley, T.C.; van den Broeke, M.R. Regional acceleration in ice mass loss from Greenland and Antarctica using GRACE time-variable gravity data. Geophys. Res. Lett. 2015, 41, 8130-8137. [CrossRef]

75. Frezzotti, M.; Pourchet, M.; Flora, O.; Gandolfi, S.; Gay, M.; Urbini, S.; Vincent, C.; Becagli, S.; Gragnani, R.; Proposito, M.; et al. New estimations of precipitation and surface sublimation in East Antarctica from snow accumulation measurements. Clim. Dyn. 2004, 23, 803-813. [CrossRef]

(C) 2018 by the authors. Licensee MDPI, Basel, Switzerland. This article is an open access article distributed under the terms and conditions of the Creative Commons Attribution (CC BY) license (http:// creativecommons.org/licenses/by/4.0/). 